PENELITIAN | RESEARCH

\title{
Preferensi Tanaman Tempat Aktivitas Aedes di Pekarangan Rumah Desa Kopelma Banda Aceh
}

\author{
The Preferred Plant by Aedes in Houseyard of Kopelma Village Banda Aceh \\ Elita Agustina ${ }^{1 *}$, Widya Sari ${ }^{2}$, Ahmad Ofreza ${ }^{1}$ \\ 1 Departemen Pendidikan Biologi, Fakultas Tarbiyah dan Keguruan, UIN Ar-Raniry, Aceh \\ 2 Departemen Biologi, Fakultas MIPA, Universitas Syiahkuala, Aceh
}

\begin{abstract}
The existence of plants in house yard is an important factor for the survival of Aedes. House yard plants could be the places where mosquitoes carry out eating and resting activities. It is important to investigate the matter to find out about mosquitoes' bioecology in the environment. The purpose of this study was to determine the species of house yard plant that were selected by Aedes for eating and resting activities. This was an explorative survey using 50 house yards. The result showed that at the Kopelma Village there were 2 species of Aedes found in house yard plant that were Aedes aegypti and Aedes albopictus. The mosquitoes were found at 6 house yard plant species that were Mangifera indica, Annona muricata, Pteridium aquilinum, Ixora $s p$., Plumeria $s p$., and Murraya $s p$.
\end{abstract}

Keywords: Aedes, mosquito activity, Kopelma Village, preferences, plant species

\begin{abstract}
Abstrak. Keberadaan tanaman di pekarangan rumah merupakan faktor penting bagi kelangsungan hidup Aedes. Tanaman pekarangan rumah dapat menjadi tempat nyamuk melakukan aktivitas makan dan istirahat. Oleh karena itu, perlu dilakukan penelitian untuk mengetahui bioekologi nyamuk di lingkungan. Tujuan penelitian ini adalah untuk mengetahui spesies tanaman perkarangan rumah yang menjadi tempat aktivitas Aedes dalam mencari makan dan istirahat. Metode yang digunakan dalam penelitian ini adalah metode survei eksploratif. Pekarangan rumah yang disurvei adalah sebanyak 50 rumah. Penelitian menemukan 2 spesies Aedes pada tanaman pekarangan rumah yaitu Aedes aegypti dan Aedes albopictus. Kedua spesies Aedes ditemukan pada 6 spesies tanaman pekarangan rumah yaitu Mangifera indica, Annona muricata, Pteridium aquilinum, Ixora sp., Plumeria sp., dan Murraya sp.
\end{abstract}

Kata kunci : Aedes, aktivitas nyamuk, Desa Kopelma, preferensi, spesies tanaman

* Korespondensi: elita_97@yahoo.com | Tel./Faks: +62 85277417176 


\section{PENDAHULUAN}

Kota Banda Aceh sebagai wilayah endemis Demam Berdarah Dengue (DBD) terus melakukan tindakan pengendalian, namun jumlah kasus DBD sulit untuk dikurangi. Sepanjang Januari sampai Juni 2017 kasus DBD di Kota Banda Aceh mencapai 216 kasus dengan tingkat kejadian $89,5 \%$. Salah satu tempat ditemukannya kasus DBD adalah Desa Kopelma. ${ }^{1}$

Desa Kopelma adalah daerah yang mobilitas penduduknya sangat tinggi dan juga termasuk salah satu daerah endemis DBD di Kota Banda Aceh karena setiap tahunnya selalu ditemukan kasus DBD. ${ }^{2}$ Tingginya mobilitas penduduk karena Desa Kopelma merupakan kawasan di sekitar kampus Universitas Islam Negeri ArRaniry dan Universitas Syiah Kuala. Kawasan ini merupakan kawasan padat penduduk karena menjadi tempat bermukimnya civitas academica kedua universitas tersebut. Penelitian Zulfikar menyatakan bahwa faktor kondisi lingkungan pemukiman yang padat dan sistem drainase yang tidak baik memengaruhi kepadatan populasi Aedes aegypti. ${ }^{3}$ Umumnya masyarakat sering menggunakan cara pengendalian nyamuk secara kimia, karena cara ini cepat menunjukkan hasilnya dan mudah untuk dilakukan. Namun cara tersebut tidak dapat menyelesaikan masalah secara tuntas karena sifatnya yang temporer. Sebaiknya pengendalian nyamuk vektor DBD dilakukan secara komprehensif dari berbagai aspek kehidupan nyamuk, seperti mengenal lingkungan hidup nyamuk dan faktor-faktor yang mendukungnya.

Nyamuk membutuhkan tiga macam tempat untuk kelangsungan hidupnya yaitu tempat berkembang biak, tempat mencari makan, dan tempat istirahat. Tempat mencari makan nyamuk yang umumnya banyak diketahui adalah tempat di mana darah inang dapat diperoleh padahal makanan utama nyamuk jantan dan betina adalah cairan manis tumbuhan seperti nektar, sedangkan darah hanya dikonsumsi oleh nyamuk betina saja untuk kebutuhan perkembangan telur. Oleh sebab itu, tumbuhan mempunyai peranan penting bagi kehidupan nyamuk, baik sebagai tempat mencari makan dan tempat istirahat. Penelitian yang dilakukan Gunter Muller menemukan bahwa dengan mengeliminasi tanaman mesquite (Prosopis juliflora) yang menjadi sumber makanan Anopheles, dapat mengurangi populasi nyamuk vektor malaria sebesar 69\%. Hal ini berdampak terhadap menurunnya penularan penyakit malaria di Mali Afrika. ${ }^{4}$ Penelitian Vincent menunjukkan bahwa nyamuk memiliki ketertarikan pada spesies tumbuhan tertentu (tumbuhan inang). Pemilihan tumbuhan inang ini dipengaruhi oleh sistem olfaktori nyamuk. Sehingga dibutuhkan penelitian lebih lanjut di lapangan sebagai suatu strategi dalam pengendalian nyamuk seperti membuat cairan manis tumbuhan yang bersifat toksik. ${ }^{5}$

Sejauh ini penelitian tentang spesies tanaman pekarangan rumah sebagai sumber makanan Aedes belum banyak diketahui. Berdasarkan hal tersebut, maka tujuan penelitian ini adalah untuk mengetahui preferensi spesies tanaman pekarangan rumah yang menjadi pilihan Aedes sebagai tempat mencari makan dan istirahat. Informasi spesies tanaman pekarangan rumah tempat aktivitas nyamuk ini penting diketahui sebagai dasar dalam menyusun strategi pengendalian Aedes.

\section{BAHAN DAN METODE}

Penelitian ini diawali dengan survei pendahuluan menggunakan metode eksplorasi untuk mengetahui kondisi umum lingkungan lokasi penelitian yaitu Desa Kopelma Banda Aceh. Penelitian ini menggunakan metode survei eksploratif. Data diperoleh melalui identifikasi jenis-jenis Aedes di pekarangan dan tanaman tertentu yang menjadi kesukaan nyamuknyamuk tersebut untuk makan dan istirahat.

Penentuan pekarangan rumah sebagai lokasi pengamatan dilakukan secara purposive. Pemilihan tersebut berdasarkan adanya tanaman dan wadah tampungan air buatan maupun alami yang terdapat di pekarangan rumah. Jumlah sampel pekarangan rumah yang disurvei sebanyak 50 rumah. Pengamatan dan penangkapan nyamuk pada tanaman dilakukan pada pagi hari dan sore hari yaitu pada pukul 06.00-10.00 WIB dan 16.00-18.00 WIB. Pemilihan waktu tersebut berdasarkan hasil penelitian Chadee et al., yang menyatakan bahwa puncak Ae. aegypti mengonsumsi cairan gula di laboratorium pada waktu pagi dan sore hari. ${ }^{6}$ Selain itu kehadiran nyamuk pada tumbuhan juga dipengaruhi oleh waktu sekresi nektar dan suhu lingkungan. ${ }^{7}$ Pengamatan dilakukan pada setiap bagian tumbuhan mulai dari batang, daun, bunga, dan buah. Nyamuk yang diduga sedang mengisap cairan tumbuhan (probosis menusuk bagian tumbuhan tertentu) ditangkap menggunakan aspirator dan dimasukkan ke dalam gelas kertas berlabel dan dicatat informasi waktu penangkapan, lokasi penangkapan, spesies tumbuhan, serta bagian tumbuhan yang dimanfaatkan. Spesies Aedes dan tanaman pekarangan rumah yang didapatkan selanjutnya dibawa ke laboratorium untuk diidentifikasi. Data spesies nyamuk Aedes dan spesies tanaman pekarangan tersebut dianalisis secara deskriptif. Setelah data dianalisis selanjutnya dilakukan 
interpretasi terhadap data yang dihasilkan dan terakhir diambil suatu kesimpulan.

\section{HASIL}

\section{Spesies Aedes yang Ditemukan pada Tumbuhan di Pekarangan Rumah}

Berdasarkan hasil penelitian di pekarangan rumah penduduk Desa Kopelma ditemukan 2 spesies Aedes yaitu Ae. aegypti dan Ae. albopictus. Aktivitas Aedes pada tanaman pekarangan rumah paling banyak ditemukan pada waktu pagi hari. Data hasil identifikasi spesies nyamuk Aedes pada tanaman pekarangan rumah dapat dilihat pada gambar 1 .

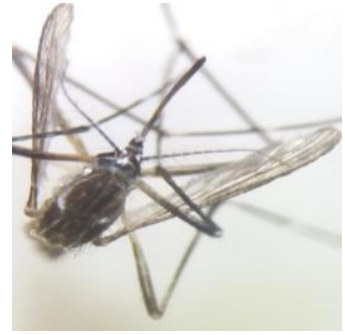

A

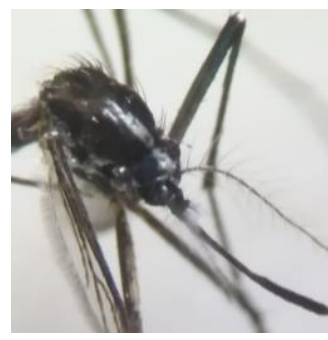

B
Gambar 1. Nyamuk Aedes Dewasa (A: Ae. aegypti, B: Ae. albopictus)

Spesies Aedes yang ditemukan pada tanaman pekarangan rumah Desa Kopelma dapat dilihat pada Tabel 1.

Tabel 1. Komposisi Spesies Aedes pada Tanaman di Pekarangan Rumah Desa Kopelma

\begin{tabular}{lcc}
\hline \multicolumn{1}{c}{ Spesies } & Jantan & Betina \\
\hline Aedes aegypti & $40 \%$ & $60 \%$ \\
Aedes albopictus & $33,3 \%$ & $66,6 \%$ \\
\hline
\end{tabular}

Tabel 1 menunjukkan bahwa ada 2 spesies Aedes yang ditemukan pada tanaman pekarangan rumah yaitu Ae aegypti dan Ae. albopictus. Spesies Ae. aegypti dan Ae. albopictus betina yang ditemukan pada tanaman pekarangan lebih tinggi dibandingkan jantan. Selain genus Aedes ditemukan juga genus lainnya yaitu Culex.

\section{Spesies Tanaman Pekarangan Rumah Tempat Nyamuk Dewasa Aedes Beraktivitas}

Hasil penelitian menemukan adanya 6 spesies tanaman tempat nyamuk dewasa Aedes beraktivitas. Spesies tumbuhan ini meliputi 6 famili yang terdiri atas famili Anacardiaceae (mangga), famili Annonaceae (sirsak), famili Pteridaceae (paku), famili Apocynaceae (Soka), famili Rubiaceae (kamboja), dan famili Rutaceae (kari). Spesies tanaman tempat ditemukan Aedes dapat dilihat pada Tabel 2 .

Tabel 2. Spesies Tanaman Tempat Ditemukan Aedes di Desa Kopelma

\begin{tabular}{lll}
\hline \multicolumn{1}{c}{ Famili } & \multicolumn{1}{c}{ Spesies Tanaman } & \multicolumn{1}{c}{$\begin{array}{c}\text { Nama } \\
\text { Daerah }\end{array}$} \\
\hline Anacardiaceae & Mangifera indica & Mangga \\
Annonaceae & Annona muricata & Sirsak \\
Pteridaceae & Pteridium aquilinum & Paku \\
Apocynaceae & Ixora sp. & Soka \\
Rubiaceae & Plumeria sp. & Kamboja \\
Rutaceae & Murraya sp. & Kari \\
\hline
\end{tabular}

Berdasarkan Tabel 2 terlihat bahwa tanaman tempat ditemukannya nyamuk dewasa Aedes berupa jenis tanaman yang sehari-hari mudah dijumpai dan ada di pekarangan rumah seperti tanaman hias (kamboja, Soka, dan paku), tanaman buah-buahan (mangga dan sirsak), dan bumbu masakan (kari). Bagian tanaman tempat ditemukannya Aedes melakukan aktivitas makan dan istirahat dapat dilihat pada Tabel 3.

Tabel 3. Bagian Tanaman Tempat Ditemukan Aedes Beraktivitas

\begin{tabular}{lccc}
\hline \multirow{2}{*}{ Spesies Tanaman } & \multicolumn{3}{c}{ Bagian Tanaman } \\
\cline { 2 - 4 } & Daun & Bunga & Batang \\
\hline Mangifera indica & $\sqrt{ }$ & - & - \\
Annona muricata & $\sqrt{ }$ & - & - \\
Pteridium aquilinum & $\sqrt{ }$ & - & - \\
Ixora sp. & $\sqrt{ }$ & - & - \\
Plumeria sp. & $\sqrt{ }$ & - & - \\
Murraya sp. & $\sqrt{ }$ & - & - \\
\hline Keterangan: $\sqrt{ }=$ ditemukan & &
\end{tabular}

- = tidak ditemukan

Tabel 3 menunjukkan bagian organ tanaman tempat Aedes melakukan aktivitas makan dan istirahat pada organ daun. Posisi Aedes pada daun meliputi bagian permukaan atas daun, bawah daun, dan tepi daun.

Aktivitas nyamuk dewasa Aedes pada tanaman pekarangan rumah terdiri dari aktivitas makan dan aktivitas istirahat. Aktivitas Aedes pada tanaman pekarangan rumah pada saat ditemukan dapat dilihat pada Tabel 4 .

Tabel 4. Aktivitas Aedes pada Tanaman di Pekarangan Rumah Desa Kopelma

\begin{tabular}{lcc}
\hline \multirow{2}{*}{ Spesies Tanaman } & \multicolumn{2}{c}{ Aktivitas } \\
\cline { 2 - 3 } & Makan & Istirahat \\
\hline Mangifera indica & $\sqrt{ }$ \\
Annona muricata & & $\sqrt{ }$ \\
Pteridium aquilinum & & $\sqrt{ }$ \\
Ixora sp. & $\sqrt{ }$ & $\sqrt{ }$ \\
Plumeria sp. & $\sqrt{ }$ & \\
Murraya sp. & & $\sqrt{ }$ \\
\hline
\end{tabular}

Tabel 4 menunjukkan bahwa aktivitas nyamuk yang paling banyak ditemukan adalah 
aktivitas istirahat. Aktivitas istirahat dilakukan pada 4 spesies tanaman, yaitu pada Mangifera indica, Annona muricata, Pteridium aquilinum, dan Murraya sp. Adapun aktivitas makan teramati pada tanaman Ixora sp. dan Plumeria sp.

\section{PEMBAHASAN}

\section{Spesies Aedes yang Ditemukan pada Tanaman di Pekarangan Rumah}

Hasil penelitian menemukan dua spesies Aedes yaitu Ae. aegypti dan Ae. albopictus. Kedua spesies nyamuk tersebut termasuk ke dalam vektor tular DBD. Aedes termasuk ke dalam ordo Diptera, famili Culicidae, subfamili Culicinae, dan genus Aedes. ${ }^{8}$

Hasil penelitian menunjukkan komposisi nyamuk betina Ae. aegypti dan Ae. albopictus lebih tinggi dibandingkan jantan. Penelitian Qualls et al., menemukan jumlah nyamuk betina yang tertangkap pada tanaman yang terpapar cairan gula sukrosa di lapangan lebih banyak dibandingkan dengan nyamuk jantan. Hal ini disebabkan karena nyamuk betina membutuhkan lebih banyak energi untuk aktivitas reproduksi. ${ }^{9}$

Penelitian di laboratorium menunjukkan bahwa Ae. aegypti jantan dan betina mempunyai periode waktu tertentu dalam mengonsumsi cairan gula. Puncak konsumsi cairan gula tertinggi nyamuk jantan dan betina terjadi pada pukul 06.00-08.00 pagi dan pukul 16.00-18.00. Namun ada perbedaan konsentrasi cairan gula yang dikonsumsi jantan dan betina. Perbedaan kosentrasi cairan gula yang dikosumsi ini terkait kebutuhan energi yang digunakan untuk berbagai aktivitas seperti aktivitas terbang mencari makan, istirahat, dan reproduksi. Selain itu juga dipengaruhi oleh faktor fisik lingkungan seperti suhu, kelembapan, dan intensitas cahaya. Konsentrasi cairan gula yang dikonsumsi nyamuk jantan pada pukul $06.00-08.00$ adalah $16 \%$, sedangkan nyamuk betina adalah $18 \%$. Adapun pada pukul 16.00-18.00 kandungan cairan gula yang dikonsumsi jantan sebanyak $40 \%$ dan betina $42 \%{ }^{7}$

Tumbuhan merupakan sumber makanan penting bagi nyamuk jantan dan betina. Cairan tumbuhan sangat dibutuhkan untuk menjalankan proses metabolisme tubuh. Namun, setiap spesies nyamuk bisa berbeda dalam memilih tumbuhan inang karena dipengaruhi oleh sistem olfaktori nyamuk terhadap senyawa volatil (bau) tanaman. ${ }^{5}$ Hasil penelitian Bellini et al menunjukkan bahwa nyamuk jantan hanya dapat bertahan hidup 4 sampai 5 hari tanpa diberikan cairan gula. Cairan gula ini segera dicari oleh nyamuk jantan setelah eklosi. ${ }^{10}$
Selain Aedes, juga ditemukan nyamuk lainnya di pekarangan rumah Desa Kopelma yaitu dari genus Culex. Namun yang umumnya mendominasi pada saat observasi adalah Aedes. Hal ini terkait waktu pengamatan pada pagi dan sore hari yang merupakan waktu aktif Aedes, dan preferensi nyamuk yang berbeda-beda terhadap tanaman di pekarangan rumah.

\section{Spesies Tanaman Pekarangan Rumah Tempat Nyamuk Dewasa Aedes Beraktivitas}

Tanaman perkarangan rumah yang menjadi tempat aktivitas Ae. aegypti dan Ae. albopictus adalah famili Anacardiaceae (mangga), famili Annonaceae (sirsak), famili Pteridaceae (paku), famili Apocynaceae (soka), famili Rubiaceae (kamboja), famili Rutaceae (kari/daun kari).

Penelitian Nyasembe et al., menyatakan bahwa pemilihan spesies tanaman yang bervariasi terkait dengan senyawa volatil yang dihasilkan oleh masing-masing tanaman. Sistem olfaktori Ae. aegypti, Ae. Mcintoshi, dan Anopheles gambiae dapat mendeteksi senyawa volatil yang berbeda-beda pada tanaman Ricinus communis, Hibiscus heterophyllus, Opuntia ficus, Senna uniflora, dan Senna alata. Ae. aegypti sebagian besar mendeteksi benzenoid, Ae. mcintoshi mendeteksi sebagian besar aldehida, sedangkan An. gambiae mendeteksi seskuiterpen dan alkena. Senyawa monoterpen $\beta$-myrcene dan (E) - $\beta$-ocimene secara konsisten terdeteksi oleh semua spesies nyamuk dan senyawa tersebut ada pada semua tanaman inang yang diidentifikasi. ${ }^{5}$

Nyamuk membutuhkan tanaman pekarangan rumah seperti tanaman Ixora sp. dan Plumeria sp. untuk melakukan aktivitas makan. Aktivitas makan nyamuk ditemukan pada bagian daun karena daun juga mengandung glukosa dari hasil proses fotosintesis. Saat nyamuk mengisap cairan pada daun, posisi tubuh nyamuk sedikit menungging atau membentuk sudut, diduga kondisi ini untuk memberi tekanan probosis pada saat menusuk. Posisi hinggap nyamuk pada daun sirsak untuk makan tepat di bawah daun. Posisi nyamuk yang mengantung di bawah daun untuk mengisap cairan tumbuhan merupakan perilaku yang unik. Imago nyamuk mempunyai perilaku makan yang sama yaitu mengisap nektar dan cairan tumbuhan sebagai sumber energi utama. Namun untuk imago betina membutuhan energi tambahan lain yaitu cairan darah. Cairan darah yang mengandung protein dibutuhkan untuk keperluan proses pematangan telurnya. ${ }^{11}$

Hasil pengamatan aktivitas nyamuk pada saat istirahat menunjukkan cara dan posisi yang berbeda dengan aktivitas makan. Perilaku nyamuk istirahat dapat ditandai dengan probosis nyamuk tidak dalam keadaan menusuk ke daun, 
tetapi berada di atas permukaan daun. Nyamuk dikatakan beristirahat apabila nyamuk berada di atas permukaan tanaman dalam jangka waktu yang relatif lebih lama dan sangat tergantung pada faktor fisik lingkungan seperti angin dan cahaya. Berbeda dengan nyamuk yang hinggap di tumbuhan yang sifatnya sementara atau singgah saja.

Pada daun mangga ditemukan kehadiran nyamuk untuk melakukan aktivitas istirahat. Daun mangga memiliki struktur panjang dan tebal yang sesuai untuk aktivitas istirahat nyamuk. Hasil pengamatan terlihat Aedes beristirahat pada bagian bawah daun mangga. Bagian bawah daun mangga lebih teduh dan terhindar dari paparan cahaya pada siang hari. Hasil penelitian Samson DM et al., menunjukkan bahwa Ae. albopictus akan beristirahat selama siang hari di vegetasi yang biasa ditemukan di sekitar daerah pemukiman, sehingga menunjukkan bahwa lanskap dapat memengaruhi distribusi spesies nyamuk di suatu daerah. ${ }^{12}$ Daun mangga selain sebagai tempat istirahat Aedes juga memiliki potensi sebagai sumber makanan karena mengandung sukrosa yang dibutuhkan sebagai sumber makanan. Sukrosa pada tumbuhan dihasilkan dari fotosintesis. Produksi gula disekresikan oleh kelenjar nektaris tumbuhan yang dapat berkembang pada bunga, batang, dan daun. ${ }^{13}$

Daun sirsak merupakan salah satu daun yang didatangi oleh nyamuk untuk aktivitas istirahat. Namun diduga Aedes tidak sekadar melakukan aktivitas istirahat, tetapi daun tersebut juga menjadi sumber makanannya. Daun sirsak memiliki karakteristik berbentuk elips, memanjang, atau bulat menyempit. Bagian ujung daun meruncing dan permukaan daun halus serta mengilat. Warna daun bagian atas lebih berwarna hijau tua dibandingkan permukaan bawah daun. Bunga tanaman sirsak termasuk jenis bunga tunggal. ${ }^{14}$ Kandungan daun sirsak adalah kalsium, fosfor, dan karbohidrat. Cairan manis yang terdapat pada daun dalam bentuk sukrosa. ${ }^{13}$

Tumbuhan paku awalnya hanya tumbuhan liar yang tidak diminati oleh masyarakat dan cenderung diabaikan. Namun sekarang tumbuhan paku telah berubah fungsi menjadi tanaman pekarangan. Tanaman paku yang ditemukan di pemukiman adalah dari jenis Pteridium aquilinum. Tanaman paku selain dimanfaatkan sebagai tanaman hias juga dimanfaatkan sebagai obat tradisional dan bahan pangan. ${ }^{15}$ Berdasarkan hasil penelitian ini, pada tanaman paku (Pteridium aquilinum) di pekarangan rumah ditemukan Aedes yang istirahat. Diduga tertariknya nyamuk pada tanaman ini karena daunnya yang berlapis-lapis atau bertindih-tindih merupakan tempat yang baik untuk bersembunyi atau istirahat. Selain itu tanaman paku tidak membutuhkan cahaya yang banyak, sehingga sering diletakkan di teras rumah. Suasana tersebut sangat sesuai untuk mendukung kehidupan nyamuk.

Soka (Ixora sp.) adalah salah satu tanaman hias yang mempunyai nilai estetika yang cukup tinggi, ini dapat terlihat dari peranannya yang cukup menonjol sebagai tanaman hias. Soka termasuk kedalam kelompok tumbuhan perdu. Tanaman soka mempunyai karakteristik daunnya berbentuk lonjong, bunganya termasuk bunga majemuk, dan warna bunganya bervariasi seperti merah jingga, merah muda, putih, dan kuning. Selain bunga, tanaman soka juga memiliki buah yang berwarna merah kehitaman dan memiliki rasa yang manis. ${ }^{16}$ Kehadiran nyamuk pada tanaman soka ini diduga karena daya tarik warna bunga dan kandungan nektarnya. Penelitian Dieng et al., menyatakan bahwa Ae. aegypti memiliki ketertarikan pada warna bunga, bentuk bunga, kelopak bunga, dan kandungan gula bunga atau nektar. Bunga yang mengandung cairan gula menjadi daya tarik bagi nyamuk untuk melakukan aktivitas makan dan istirahat. Kondisi ini dapat menjadi perangkap untuk menangkap nyamuk seperti Ae. aegypti. Tumbuhan berbunga yang digunakan untuk memerangkap nyamuk tersebut dibedakan berdasarkan warna bunga biru, merah, kuning, merah muda, dan ungu. ${ }^{17}$

Pohon Kamboja (Plumeria sp.) termasuk ke dalam kelompok tumbuhan perdu yang memiliki estetika tinggi. Daya tarik tumbuhan kamboja adalah pada bunganya yang bervariasi dan aromanya yang harum. Hampir semua bagian tumbuhan kamboja mempunyai manfaat seperti akar, batang, getah, daun, kulit batang, dan bunga. ${ }^{18}$ Hasil penelitian Widiyatna et al., menunjukkan pada daun kamboja mengandung karbohidrat.19 Daun merupakan tempat yang umumnya sering dihinggapi nyamuk karena bentuk daun yang lebar memudahkan nyamuk untuk melakukan aktivitas istirahat dan makan. Aktivitas makan dilakukan langsung setelah nyamuk eklosi.

Tanaman kari (Murraya sp.) tergolong ke dalam famili Rutaceae merupakan salah satu tanaman yang dihinggapi nyamuk. Tanaman ini memiliki aroma daun yang khas, bentuk daun bulat telur, dan jumlah daun dalam satu tangkai lebih dari satu yang disebut dengan daun majemuk. Daun berwarna hijau muda dan helaian daunnya tipis. Tanaman kari mempunyai bunga yang kecil berwarna putih kekuningan. Daun kari banyak terdapat di Provinsi Aceh, dan dimanfaatkan secara luas oleh masyarakat sebagai rempah penyedap masakan. Daun kari 
dalam Bahasa Aceh disebut juga sebagai "daun temurui". Berdasarkan pengamatan di lapangan ditemukan nyamuk dewasa Aedes hinggap pada daun kari dan melakukan aktivitas istirahat. Diduga selain melakukan aktivitas istirahat, nyamuk ini juga melakukan aktivitas makan. Hal ini disebabkan salah satu kandungan daun kari adalah karbohidrat. Berdasarkan penelitian Sirait, daun kari mengandung karbohidrat sebanyak $16 \% .^{20}$

\section{KESIMPULAN}

Spesies Aedes yang ditemukan di pekarangan rumah Desa Kopelma Kota Banda Aceh adalah Ae. aegypti dan Ae. albopictus. Spesies tanaman pekarangan rumah tempat aktivitas nyamuk adalah Mangifera indica, Annona muricata, Pteridium aquilinum, Ixora sp., Plumeria sp., dan Murraya sp. Keberadaan Aedes pada tanaman pekarangan rumah untuk melakukan aktivitas makan dan istirahat.

\section{UCAPAN TERIMA KASIH}

Penulis menyampaikan terima kasih kepada pimpinan Universitas, Fakultas, dan Program Studi Pendidikan Biologi UIN Ar-Raniry, atas kesempatan serta dukungan penelitian yang telah diberikan. Terima kasih pula kepada "Tim Jumantik Instar II" atas bantuan dan kerjasamanya dalam menyelesaikan penelitian dan tulisan ini.

\section{KONTRIBUSI PENULIS}

Peran penulis pada artikel ini, yaitu Elita Agustina sebagai kontributor utama. Widya Sari dan Ahmad Ofreza sebagai kontributor anggota. Kontribusi penulis dapat dilihat pada rincian berikut:

$\begin{array}{lll}\text { Konsep } & : \text { Elita Agustina } \\ \begin{array}{l}\text { Sponsor } \\ \text { Pendanaan }\end{array} & : \text { Elita Agustina } \\ \text { Investigasi } & : & \text { Semua Penulis } \\ \text { Metodologi } & : & \text { Elita Agustina } \\ & & \text { Widya Sari } \\ \text { Manajemen } & : & \text { Semua Penulis } \\ \text { Proyek } & & \\ \text { Sumber Daya } & : & \text { Semua Penulis } \\ \text { Pengawasan } & : & \begin{array}{l}\text { Elita Agustina } \\ \text { Widya Sari }\end{array}\end{array}$

$\begin{array}{lcc}\text { Visualisasi } & : & \begin{array}{l}\text { Elita Agustina } \\ \text { Ahmad Ofreza }\end{array} \\ \begin{array}{l}\text { Menulis- } \\ \text { Pembuatan Draft }\end{array} & : & \begin{array}{l}\text { Elita Agustina } \\ \text { Ahmad Ofreza }\end{array} \\ \begin{array}{l}\text { Menulis- } \\ \text { Mengkaji \& } \\ \text { Mengedit }\end{array} & \text { Elita Agustina } \\ \text { Ahmad Ofreza }\end{array}$

\section{DAFTAR RUJUKAN}

1. Nufara E, a , Ghufron Mukti A, T. Satoto Mail TB. Financing of Dengue Hemorrhagic Fever Control Program in Banda Aceh City. J Medicoeticolegal dan Manaj Rumah Sakit. 2018;7(1):22-32. doi:10.18196/jmmr.7153

2. Dinkes Aceh. Kota Banda Aceh Tahun 2016. Banda Aceh; 2017.

3. Zulfikar. Status Kerentanan Aedes aegypti Dan Kaitannya dengan Penggunaan Insektisida di Permukiman Kota Banda Aceh. 2017. http://repository.ipb.ac.id/handle/123456 789/83291.

4. Muller GC, Junnila A, Traore MM, et al. The Invasive Shrub Prosopis Juliflora Enhances the Malaria Parasite Transmission Capacity of Anopheles Mosquitoes: a Habitat Manipulation Experiment. Malar J. 2017;16(237):2-9. doi:10.1186/s12936017-1878-9

5. Nyasembe VO, Tchouassi DP, Pirk CWW, Sole CL, B. Torto. Host Plant Forensics and Olfactory-based Detection in Afro-tropical Mosquito Disease Vectors. PLoS Negl Trop Dis. 2018;12(2). doi:https://doi.org/10.1371/journal.pntd.0 006185

6. Pachuwah P. The Role of Floral and Fruit Scent Compounds as Mosquito Attractants: Developing New Methods for Monitoring Mosquito Populations. 2016;(May). http://hdl.handle.net/10413/14121.

7. Chadee DD, Sutherland JM, Gilles JRL. Diel Sugar Feeding and Reproductive Behaviours of Aedes Aegypti Mosquitoes in Trinidad: with Implications for Mass Release of Sterile Mosquitoes. Acta Trop. 2014;132:86-90. doi:10.1016/j.actatropica.2013.09.019

8. Higa Y, Abilio AP, Futami K, Lazaro MA, Minakawa N, Gudo ES. Abundant Aedes (Stegomyia) aegypti Mosquitoes in the 2014 Dengue Outbreak Area of Mozambique. Trop Med Heal. 2015;43(2). doi:10.2149/tmh.2014-29

9. Qualls WA, Müller GC, Revay EE, et al. Evaluation of Attractive Toxic Sugar Bait 
(ATSB)-Barrier for Control of Vector and Nuisance Mosquitoes and Its Effect on Nontarget Organisms in Sub-tropical Environments in Florida. Acta Trop. 2014. doi:10.1016/j.actatropica.2013.12.004

10. Bellini R, Puggioli A, Balestrino F, et al. Sugar Administration to Newly Emerged Aedes Albopictus Males Increases Their Survival Probability and Mating Performance. Acta Trop. 2014. doi:10.1016/j.actatropica.2013.11.022

11. Agustina E. Serangga Hama Permukiman (Nyamuk \& Lalat). Yayasan Ummi; 2016.

12. Samson DM, Qualls WA, Roque D, Naranjo DP, Alimi T, Arheart KL, Müller GC, Beier JC and XR. Resting and Energy Reserves of Aedes albopictus Collected in Common Landscaping Vegetation in St. Augustine, Florida. J Am Mosq Control Assoc. 2013;29(3):231-236. doi:10.2987/136347R.1

13. Kottapalli J, David-schwartz R, Khamaisi B, et al. Sucrose-induced Stomatal Closure is Conserved Across Evolution. PLoS One. 2018;13(10):1-17.

doi:https://doi.org/10.1371/journal.pone.0 205359

14. Kurniasih N, Kusmiyati M, Sari RP WR. Potensi Daun Sirsak (Annona Muricata Linn), Daun Binahong (Anredera Cordifolia (Ten) Steenis), dan Daun Benalu Mangga (Dendrophthoe Pentandra) sebagai Antioksidan Pencegah Kanker. J Istek. 2015;9(1).

15. Ridianingsih DS, Pujiastuti, Hariani SA.
Inventarisasi Tumbuhan Paku (Pteridophyta) di Pos Rowobendo-Ngagelan Taman Nasional Alas Purwo Kabupaten Banyuwangi. bioeksperimen. 2017;3(2):2030. doi:DOI: https://doi.org/10.23917/bioeksperimen.v 3i 2.5179

16. Hasanuddin. Etnobotani Tanaman Hias di Tanah Jambo Aceh Utara. In: Prosiding Seminar Nasional Biotik 2015. Banda Aceh: Prodi Pendidikan Biologi FTK UIN ArRaniry; 2015:96-111. http://jurnal.arraniry.ac.id/index.php/PBiotik/index.

17. Dieng H, Satho T, Binti Arzemi NA, et al. Exposure of a Diurnal Mosquito Vector to Floral Mimics: Foraging Responses, Feeding Patterns, and Significance for Sugar Bait Technology. Acta Trop. 2018;185(1):230238. doi:10.1016/j.actatropica.2018.05.019

18. Paramita LUHR, Sarwadana SM, Astawa ING. Identifikasi Tanaman Obat-obatan Sebagai Elemen Lunak Lanskap di Kecamatan Kediri, Kabupaten Tabanan, Provinsi Bali. E-Jurnal Arsit Lansek. 2017;3(2):117-126.

19. Prasetyo WJ, Nugraheni P, Koentjoro Y. Perubahan Kandungan Karbohidrat Tanaman Lanskap Sebagai Bioindikator Pencemaran Udara di Kota Surabaya. Plumula. 2016;5(1):50-57. http://ejournal.upnjatim.ac.id/index.php/pl umula/index.

20. Sirait N. Khasiat Daun Kari (Murraya koenigii) bagi Kesehatan. War Penelit dan Pengemb Tanam Ind. 2015;21(3):26-28. 
Preferensi Tanaman Tempat Aktivitas Aedes di Pekarangan Rumah Desa Kopelma Banda Aceh (Agustina, Elita et al.) 